\title{
Alexis Wright's Publishing History in Three Contexts: Australian Aboriginal, National, and International
}

\author{
Per Henningsgaard
}

Tn order to better understand and appreciate Alexis Wright's publishing history, it is important to first place it in the context of the publishing history of Australian Aboriginal literature. Only then can one properly situate it in the larger context of Australian literature. Finally, for full effect, Wright's publishing history should be placed in the context of the international literary marketplace. ${ }^{1}$

Scholars readily agree that the 1980 s was an important moment in the publishing history of Australian Aboriginal literature. For example, Anita Heiss and Peter Minter write, "Mainstream publishers . . . took a strong interest in Aboriginal authors, and by the end of the 1980s Aboriginal writing was firmly established as a major force in Australian letters" (6). The founding in 1987 of the Australian Aboriginal publishing house Magabala Books and the publication of Sally Morgan's My Place in the same year were undoubtedly major contributing factors. Even the controversial Australian writer Mudrooroo "asserts that the year of the bicentenary [1988] was the year in which Aboriginal literature came of age: 'It was then that it entered the mainstream of the Australian consciousness"' (Poland 90, quoting Mudrooroo 8). Indeed, within the decade of the 1980s, the "end of the 1980s" was especially significant because 1988 was the bicentennial of Australian colonization, and financial contributions by the Australian Bicentennial Authority made this moment a particularly productive one for Australian literature-even, as was the case with many Australian Aboriginal writers, if they were writing in ways that were critical of the bicentennial celebrations (Turner 2). Of course, the publishing history of Australian Aboriginal literature begins earlier than the 1980s; for example, the first Australian Aboriginal writer to have a book published was David Unaipon in 1929 (Munro 150). Kath Walker's book of poetry We Are Going (1964) is arguably the next major milestone in the publishing history of Australian Aboriginal literature (Munro 151). Nonetheless, as Heiss writes in her seminal book on the subject, Dhuuluu-Yala-To Talk Straight: Publishing Indigenous Literature (2003), "Aboriginal written literature did not fully develop into a distinct genre until the 1970s, 80s and 90s" (25).

Wright did not receive her first publication credit until 1995, so her writing career does not align with this trend identified by scholars of Australian Aboriginal literature and its publishing history. Nonetheless, she has benefited from the growth of interest in Australian Aboriginal literature in the wake of-and as part 
of the resistance to-the 1988 Australian bicentennial celebrations (not to mention the international growth of interest in indigenous literatures that happened around the same time, which is especially evident in settler colonial countries such as Australia, Canada, and New Zealand). This first publication credit was for a poem published in 1995. The poem, "Dead Man's Mile," was included in a slim, seventy-page anthology titled Voices from the Heart: Contemporary Aboriginal Poetry from Central Australia (1995), which was published by IAD Press, an Australian Aboriginal publishing house. IAD Press was established in Alice Springs in 1972 as "the publishing arm of the educational college, the Institute of Aboriginal Development" (Heiss 51).

One year after the publication of this first poem, Wright's first work of prose appeared in print. Wright entered her unpublished short story "When Devils Call" into the competition for a Northern Territory Literary Award, where it won an award designated for Aboriginal and Torres Strait Islander writers. The story was then selected for inclusion in an anthology titled Extra-Territorial: Stories and Poems from the Northern Territory Literary Awards, which was published in 1996 by NTU Press (a division of Northern Territory University, which has since changed its name to Charles Darwin University).

Remarkably, it was not long after the publication of Wright's first poem and first work of prose that the public got its first hint of Wright's potential for something much larger. In 1996, Wright published "Untitled (from Requiem for Ivy)," an excerpt from a novel-in-progress. This excerpt was published in the Melbournebased Meanjin, one of Australia's best-known literary journals. The following year, Wright published two books: Plains of Promise (1997), which incorporated the aforementioned excerpt, and Grog War (1997). There are several things about this occasion that are extraordinary: First, to publish two books in a single year is a rare feat. Second, for Wright's first book to arrive a mere two years after the publication of her first poem is impressive. Finally, by the end of her third year as a published writer, Wright had published in a diversity of forms including one poem, two short stories, one novel, and one book-length work of nonfiction. Notably, Wright's first poem and her first book-length work of nonfiction would also be her last; she has not published another poem or another book-length work of nonfiction since.

Identifying the 1980s as an important moment in the publishing history of Australian Aboriginal literature is one trend about which scholars readily agree, but there are, of course, other trends. A second trend that many scholars of Australian Aboriginal literature and its publishing history have identified is that certain genres are more prominent. As Kerry Kilner and Peter Minter write, "When looking at all works published, and taking into account individual works published within other works (anthologies, periodicals, etc.), the figures dramatically show the importance of poetry in the literary activities of Aboriginal and Torres Strait Islander writers" (8). According to Kilner and Minter's statistics, poetry accounts for slightly more than one-half of all works published by Australian Aboriginal authors (9). 
Once again, Wright's early publishing history is related to this particular trend but far from the ideal representative of it, since her first published work was a poem but she has never again published poetry.

Kilner and Minter's statistics also reveal that there have been substantially more book-length works published belonging to the genre of life writing than there have been book-length poetry collections published (8). Perhaps, then, the abundance of scholarly interest in Australian Aboriginal life writing is an entirely natural outgrowth of the frequency of publication. On the other hand, some critics maintain that scholarly interest in life writing is related to a widespread belief that Australian Aboriginal life writing "represents a site where Indigenous Australian writers have achieved freedom in self-expression" (Kurtzer 20). Moreover, these critics point out that this ideology comes with baggage-specifically, a requirement that "Indigenous participants represent themselves within particular 'frames' (authentic, traditional people)" (Everett 148). Or, as Sonja Kurtzer describes it, "'White' audiences ... seek to contain these stories to those images already possessed in relation to 'otherness" (20). In other words, because non-Aboriginal readers understand life writing as a site of "authentic" self-expression suited to explorations of one's own "otherness," Australian Aboriginal authors working in this genre may feel limited by or forced to accommodate these expectations. Arguably, it is this very tension that has given rise to so much scholarly interest in the subject of Australian Aboriginal life writing.

Considering the prominence of the life-writing genre in the field of Australian Aboriginal literature, it is interesting to note the ways in which Wright has defied expectations. To begin, Wright has not published a single book-length work that could be categorized as life writing. Furthermore, her first book, Grog War, had the potential to incorporate elements of the life-writing genre, but it seems to have been constructed in such a way as to deliberately avoid any association with life writing.

Wright was commissioned by the Julalikari Council of Tennant Creek to write Grog War, a book that documents the Northern Territory community's struggle to introduce restrictions on alcohol in the town. This work of nonfiction was published by Magabala Books, which was established in 1987 and refers to itself as "Australia's oldest independent Indigenous publishing house," since it was the first publishing house to adopt the policy of publishing only those books with which an Australian Aboriginal creator was involved (Magabala Books). The publication of Grog War was extremely timely since, in addition to Tennant Creek, several other Northern Territory and Western Australian towns with sizeable Australian Aboriginal populations were debating the adoption of alcohol bans around this time. Nonetheless, the commercial success of this book was relatively limited. For example, it was not until 2009 that Magabala Books deemed necessary a reprint of Grog War. Jason Ensor describes reprints as "a commercial indicator of demand" that can stand in for reliable sales figures, which are difficult to come by ("Reprints" 203). In the case of Grog War, the publisher was probably inspired by the success of Wright's novel Carpentaria, which was published in 2006 and won the 2007 
Miles Franklin Literary Award, to issue not merely a reprint of Grog War but a new edition.

The new edition of Grog War features several changes designed to capitalize on Wright's role as author (in spite of the fact that the book's copyright is held by the Julalikari Council). For example, the 2009 edition of Grog War includes an author photo, whereas none appeared in the original publication. Furthermore, the acknowledgments section of the second edition is clearly attributed to Wright; in the first edition, it is not nearly so clear who is responsible for the acknowledgments section because, while Wright is named as the book's author, the Julalikari Council is also prominently identified on the book's cover and title page. These couple of changes that were made to the second edition draw attention to the fact that the first edition of Grog War seems to have been constructed in such a way as to downplay the role of the author, thus avoiding any association with life writing. By writing a book that opens up Australian Aboriginal life and culture to the reader but not acknowledging the author's own Australian Aboriginal heritage in the book's peritext, Grog War frustrates non-Aboriginal readers' desire "to hear 'authentic' tales of the 'other'” (Kurtzer 20).

The same year that Wright published Grog War with Magabala Books, she also published Plains of Promise with University of Queensland Press (UQP) as part of the publisher's UQP Black Australian Writers series. In contrast to Grog War, the novel Plains of Promise more quickly connected with a readership, necessitating three reprints (including a reprint in 1998, just one year after the book was published) even before Carpentaria was published in 2006 and Wright won the Miles Franklin Literary Award.

Prior to 1998, all of Wright's publications (with the exception of an excerpt from Plains of Promise published in Meanjin in 1996) had been with publishing houses with a notable commitment to Australian Aboriginal writing: IAD Press, NTU Press, Magabala Books, and UQP. Several scholars have, for example, commented on UQP's steadfast support of Australian Aboriginal writers and writing. Louise Poland writes, "With the critical development of its Black Australian Writers Series, founded in 1990, the University of Queensland Press could be reasonably described as 'the most prolific publisher of Aboriginal and Torres Strait Islander writers' in the 1990s" (84, quoting an interview with Sandra Phillips, former editor at UQP). Oliver Haag and Heiss offer a similar assessment (Haag, "From the Margins" 10; Heiss 61). It is notable, however, that all three of the aforementioned scholars (and many more besides) reference UQP in the context of discussions about "mainstream publishing houses" (Poland 84; Heiss 57) or "mainstream publishers" (Haag, "From the Margins" 10). Poland, Haag, and Heiss use these "mainstream publishing houses" as a foil for their discussions of a small number of Australian Aboriginal publishing houses including, most notably, Aboriginal Studies Press, IAD Press, and Magabala Books. Here, Haag's definition of "general" publishers, as distinct from "special" publishers, can be usefully employed to distinguish between "mainstream" 
and Australian Aboriginal publishing houses: "Based on the publishing program, I differentiate between general and special publishers. Special publishers are those with a narrow readership or with a special target subject-for example, companies that publish only 'Third World Literature.' General presses are understood to be companies that publish a variety of genres and themes" (Haag, "Indigenous" 1). This definition makes it clear that Australian Aboriginal publishing houses are "special" because of their exclusive focus on Australian Aboriginal writing as a "special target subject," whereas UQP is "mainstream" because it publishes "a variety of genres and themes."

Australian Aboriginal publishing houses are central to a third trend related to the subject of Australian Aboriginal literature and its publishing history. Scholarly attention to so-called mainstream publishing houses that are committed to publishing Australian Aboriginal literature pales in comparison to the attention that has been devoted to Australian Aboriginal publishing houses. For example, in Heiss's book Dhuuluu-Yala-To Talk Straight, she writes, "While many Aboriginal writers have come through our own publishing houses, few have come through the mainstream" (58). Heiss's own bibliography of Australian Aboriginal literature that appears as an appendix to her book demonstrates that this statement is untrue, yet her statement is likely to go uncontested because it is symptomatic of the overrepresentation of Australian Aboriginal publishing houses in the work of scholars who study Australian Aboriginal literature and its publishing history.

If, as is arguably happening, scholars are identifying a trend in the publication of Australian Aboriginal literature by Australian Aboriginal publishing houses at the expense of these same scholars' attention to the contributions of "mainstream publishing houses," this is clearly problematic. But perhaps even more significantly, scholars are misleading readers by conflating the dynamics involved in the publication of Australian Aboriginal literature to a simple dichotomy (i.e., Australian Aboriginal publishing houses versus "mainstream publishing houses"). The conflation of publishing houses as different as UQP and Giramondo Publishing (not to mention Penguin Random House or Hachette) under the banner of "mainstream publishing houses," and the scholarly neglect of this category in favor of the three Australian Aboriginal publishing houses, is suggestive of the general neglect of Wright's publishing history and the publishing history of Australian Aboriginal authors like her. This is an idea that will be returned to later in this article.

In 1998, Wright published three short stories and an essay-and, in the process, broke her established mold of working with publishing houses with a notable commitment to Australian Aboriginal writing. Wright published a short story titled "The Serpent's Covenant" in the book A Sea Change: Australian Writing and Photography (1998), which was published by the Sydney Organising Committee for the Olympic Games. Wright also placed a story, "The Chinky Apple Tree," in the politically radical, Melbourne-based literary journal Overland in 1998. This story 
appears as part of a thirty-two-page "supplement of some of the best new writing emerging in the Northern Territory," which is introduced by Marian Devitt of the Northern Territory Writers' Centre (Syson 3).

Notably, 1998 marks Wright's incursion into the so-called "'golden triangle' of Sydney-Melbourne-Canberra” (Bennett 258). This "golden triangle” represents, of course, the center of Australian culture and cultural production, especially as concerns book culture and book production. Susan McKernan (now Susan Lever), a prominent scholar of Australian literature, diagnoses the practical experiences that shape this sense of a dichotomy between the literary center and the periphery in Australia: "Writers and critics who live outside the centres of the East coast feel that their work will be overlooked by publishers and readers in the centre" (548-49). Devitt, in the aforementioned introduction to Overland's Northern Territory supplement, chimes in with her take on the consequences of this kind of oversight for writers residing on the periphery: "The development of a wide readership with opportunities for some kind of critical response is extremely difficult. With the lack of an identifiable publishing industry to support local writers there is also a limit to the professional feedback that writers can expect through trained editors and literary agents or reviews, let alone a response from a critical readership" (33). Wright seems to have escaped this trap, however, by finally finding publishers in the "'golden triangle' of Sydney-Melbourne-Canberra" that are interested in publishing her work. This movement between publishers accords with Ensor's observation, derived from his empirical methodology, that "authors within these particular states [of Queensland, Western Australia, and South Australia] ... look to Sydney and Melbourne for publishing subsequent novels" ("Still" 206). Of course, finding a publisher in the "golden triangle" also required of Wright that she look beyond those publishing houses with a notable commitment to Australian Aboriginal writing that had helped jump-start her career.

It is perhaps not a coincidence that 1998 is also the first year in which it becomes evident that Wright has entered some sort of canon of Australian Aboriginal (or even just "Australian") writers. The clearest evidence of this development is that Wright's short stories, including "The Chinky Apple Tree" and "When Devils Call," were reprinted in multiple venues in 1998. These venues range from the Tasmania-based literary journal Siglo, which ran from 1993 until 2000, to Across Country: Stories from Aboriginal Australia (1998), an anthology published by ABC Books in Sydney. Anthologies, in particular, can both suggest and confirm a literary canon; specifically, the repeated inclusion of a single writer or literary work in different anthologies has the effect of confirming the writer's status as part of a given canon.

Just as Wright was arguably entering an Australian canon, she was also being picked up overseas. In 1999, Wright inaugurated her relationship with the French publishing house Actes Sud, which published a translation of Plains of Promise titled Les plaines de l'espoir. Actes Sud's translation of this novel "has sold sufficiently well 
for it to be one of the few books to have been published as a paperback as well as a livre broche" (Barrett 58). In 2009, Actes Sud published a translation of Carpentaria, titled Carpentarie. But Actes Sud has also published some less traditional books by Wright. For example, it published a book titled Croire en l'incroyable (2000), which can be translated as "belief in the unbelievable." It is a diminutive, forty-five-page book (the trim size is only four by five and a half inches), the contents of which have not been published in English. It was, however, translated from the original English by Sabine Porte. Two years later, in 2002, Actes Sud published Le pacte du serpent arc-en-ciel, which can be translated as "the rainbow snake's covenant." The book contains the following previously published short stories: "The Serpent's Covenant," "When Devils Call," and "The Chinky Apple Tree." However, it also contains four short stories that remain unpublished in English, even though they were originally written in English by Wright and then translated into French by Sylvie Kandé and Marc de Gouvenain. These stories are titled "Lucas," "Il y a de la lumière, mais personne à la maison," "Devy," and "Le serpent de feu." The precise reason why these stories-and, moreover, Wright's only short story collection-remain unpublished in their original English is unclear, but among the possible reasons are the following: "the first and last stories of the ... collection are excerpted from Carpentaria" (Hall 4), which would not be published for another four years; "from 2000 to 2006, single-author short story collections virtually disappeared from the Australian literary marketplace" (Stinson); and, according to Wright herself, "there was no great interest in my work at that time" (qtd. in Hall 8).

Wright has published only one original short story in the nearly two decades since the release of Le pacte du serpent arc-en-ciel. This short story, "Be Careful about Playing with the Path of Least Resistance," was published in Freedom: Short Stories Celebrating the Universal Declaration of Human Rights, an anthology sponsored by Amnesty International and published by Mainstream Publishers in Edinburgh, Scotland, in 2011. That Wright has published only one original short story in the years between 2002 and 2020 is a surprising fact, especially considering Wright published nine short stories between 1995 (when she received her first byline) and 2002 for a rough average of one original short story per year. Even more surprising is the fact that, excepting "Be Careful about Playing with the Path of Least Resistance" published in 2011, Wright's last original short story published in English appeared in 1999.

In the years since, Wright has, of course, published two highly acclaimed novels, but she has also focused more of her energy on essays and criticism. These have appeared in some of Australia's best-known literary journals, such as Meanjin, Overland, and Heat. They have also appeared in the pages of several prominent newspapers, including most frequently the Age (based in Melbourne) and the Sydney Morning Herald. Many are overtly political, such as "Trapped in a Cycle of Fear" (2007), "A Question of Fear" (2008), "Where to Point the Spears?" (2011), and "We Have a Vision. What We Need Is Authority" (2007). Others are concerned with 
the authorial process, including "Special Feature: Hunger and Other Stories" (2003) and "On Writing Carpentaria" (2007). It is also evident that Wright has achieved sufficient notoriety that she is frequently asked to contribute writing on subjects related to special events. For example, "Politics of Writing" (2002) was published in Southerly but was originally written as a speech for Message Sticks, a festival celebrating Australian Aboriginal art and culture; "Secrets and Ties" (2010) was published to coincide with and celebrate the opening of the Wheeler Centre in Melbourne.

Essays and criticism, as well as the two aforementioned books published in French, filled the time between Wright's book-length works in the English language. In 2006, Wright published her novel Carpentaria. Nearly ten years had passed since Wright published Grog War and Plains of Promise, her previous two book-length works in English. Mirroring a previously discussed transition in the publication of Wright's short fiction, Carpentaria is Wright's first book published in the so-called "'golden triangle' of Sydney-Melbourne-Canberra." Carpentaria was published by Giramondo Publishing, which is based in Artarmon (a suburb of Sydney) and does not have any particular commitment to Australian Aboriginal writing. Indeed, Giramondo has "a growing reputation for making a success of books rejected by bigger publishers"; these are usually books with an experimental writing style that would be categorized as "literary fiction"-qualities perceived by the "bigger publishers" as a commercial liability (Wyndham). In other words, Giramondo's mandate has absolutely nothing to do with the identity of its writers, with the exception that it favors Australian writers. Giramondo is also well known for producing awardwinning books, which is exactly what happened with Carpentaria: it won the 2007 Miles Franklin Literary Award, Australia's most prestigious literary award. It also won prizes in the Premier's Literary Awards in New South Wales, Queensland, and Victoria, as well as several other awards.

On the back of these awards, Carpentaria was translated into French, Italian, Polish, and Chinese. ${ }^{3}$ With regard to these translated editions, it is important to note that "the Australia Council for the Arts has three specific programmes to promote the sale of Australian literature overseas" (Barrett 54). As Susan Barrett explains in her article "The Translation and Marketing of Australian Literature in France," "The first is the VIP (Visiting International Publishers) programme. Every year since 1998, the Australia Council has invited between eight and twelve foreign publishers to come to Australia at the time of a book fair and/or a writers' festival in an attempt to 'promote rights sales of Australian titles to overseas markets and to strengthen the links between Australian and overseas publishing houses and literary agencies"” (54, quoting Campbell 116). Carpentaria's French publisher (Actes Sud) participated in the VIP program in its very first year, which was 1998. Carpentaria's Italian publisher (Rizzoli) participated in the VIP program in 2004, while the Chinese publisher (People's Literature Publishing House) participated in 2007. Only Carpentaria's Polish publisher (Media Rodzina) did not participate in this program. 
Barrett describes yet another program meant to "promote the sale of Australian literature overseas": "The Australia Council for the Arts offers grants of up to $\$ 10,000$ (AUD) to help overseas publishers with translation and publishing costs" (55). Actes Sud received one of these grants to assist with the translation of Carpentaria. Indeed, Actes Sud "has ... obtained translation grants almost every year," perhaps because it "is the only mainstream French publishing company to have created a collection devoted to Australian and New Zealand books which it has called Antipodes" (Barrett 58).

Actes Sud, like the other publishers to release translations of Carpentaria, is a highly regarded publishing house in its home nation, France. The state-owned People's Literature Publishing House, for example, has been described as "one of the oldest and most prestigious publishers in China" (Grundy). This fits with Haag's observation about the publication of Australian Aboriginal literature in German translation: " $42 \%$ of the German publications have been issued by high quality presses-a remarkable development" ("Indigenous" 8). "High quality presses" are a clear trend in the publication of translated editions of Carpentaria, even though none of Wright's books have been translated into German. This omission is surprising because "the most prolific and largest market for [Australian Aboriginal] literature in translation has been continental Europe, with German being the most frequent language of translation. Out of roughly ninety translations published so far, about thirty of them are in German, followed by French, Dutch, and Italian" (Čerče 78). Nonetheless, Carpentaria's translation into four languages represented a major advancement in Wright's international reputation-even if the print runs were small (in China, for example, it had "a print run of less than two thousand copies," which meant it "was never going to have a significant impact on mainstream Chinese culture" [Osborne and Whitlock 8]).

Around the time that Carpentaria was being published in translated editions, it was also reaching an audience outside Australia through new English-language editions. Constable, an imprint of Constable and Robinson, published a British edition of the book in 2008. The following year, the US publishing house Atria International, a division of Simon and Schuster, released the American edition of Carpentaria (2009) as a hardcover and later a paperback. Carpentaria is the first of Wright's books to be published in either a British or an American edition.

Wright's follow-up novel, The Swan Book, was published in 2013, seven years after the publication of Carpentaria. Like Carpentaria, The Swan Book was published by Sydney-based Giramondo Publishing to much acclaim. It did not, however, win many literary awards. It was shortlisted for some of the same awards that Carpentaria won, such as the Miles Franklin Literary Award and the Christina Stead Prize for Fiction in the New South Wales Premier's Literary Awards. The only award it won was the ALS Gold Medal, which is sponsored by the Association for the Study of Australian Literature and which Carpentaria also won. French rights were once again sold to Actes Sud, UK rights to Constable, and North American rights to 
Atria, but other foreign rights remain unsold. Indeed, the following excerpt from Books+Publishing, a magazine for the Australasian publishing industry, is quite telling: "Giramondo Publishing made its first appearance at this year's fair [the 2013 Frankfurt Book Fair, which is the largest of its kind in the world and a prime site for foreign rights sales], with managing editor Alice Grundy seeing her trip as a 'reconnaissance mission.' Grundy, who was pitching Alexis Wright's The Swan Book, among other titles, observed that European publishers seemed more open to shorter-format titles, which have the added advantage of being less expensive to translate than longer novels" (Hanke). Coming in at 342 pages, The Swan Book is not nearly so large as the 520-page Carpentaria, but it hardly qualifies as a "shorter-format title." Grundy's comment, then, would seem to suggest that selling translation rights to Wright's latest novel has been a challenge. Other possible reasons for this difficulty include The Swan Book's relative lack of literary prizes in comparison to Carpentaria and the availability of Australia Council funding to support translations.

Indeed, it is surprising that even American and British publishing houses, which do not have to contend with the extra expense of translation, remain committed to publishing international editions of Wright's books. It is surprising because, prior to "making the case for acquiring a new book[,] an editor will routinely check the sales history of the author's previous books" (Thompson 198). John B. Thompson, author of Merchants of Culture: The Publishing Business in the Twenty-First Century (2010), elaborates on the history and significance of this act: "Thanks to [Nielsen] BookScan, the sales history of any book published after 2000/1 is now public knowledge. ... Authors carry their sales histories with them like a noose around their neck" (198). Thus, it is safe to assume that the publisher at Atria, for example, consulted the sales figures for Wright's only book with an American edition prior to entering into a new publishing agreement. It is also safe to assume that these figures were a source of concern. The hardcover and paperback versions of Carpentaria have each sold fewer than one thousand copies, which is a very poor showing. ${ }^{4}$ Compare this to Australia, where at least thirteen thousand copies of Carpentaria are in print (Wyndham). As an American editor wrote on a prominent American literary blog on the subject of Carpentaria, "When Atria published it here in the US, something odd happened-the book disappeared. No reviews. No interviews. No bookstore carried it. Nothing. It was as if Carpentaria had entered the Bermuda Triangle of American publishing" (Barron). The novel's widely acknowledged "difficulty" presumably contributed to this chilly reception, but it is also possible that its sociohistorical contexts are especially difficult to grasp for culturally foreign target readers. Perhaps, then, Wright's reputation does not extend nearly so far beyond the shores of Australia as was previously thought.

So why have Constable and Atria committed to publishing a second book by Wright? One imagines they are betting on Wright's eventual canonization in the sphere of international literary fiction. Indeed, sales of Carpentaria to libraries in the United States (which are not captured by Nielsen BookScan) suggest that 
canonization is a possibility: "It can be shown how widely the book was distributed in library networks ... by drawing on the holdings data of worldcat.org. More than six hundred libraries bought and hold at least one copy of the American edition of Alexis Wright's Carpentaria" (Osborne and Whitlock 3). Even though sales of the book to the American public were lacking, a healthy volume of library sales suggests that Wright's reputation with gatekeepers is alive and well. However, how much longer American and British publishers will continue to back this particular bet is an important question for the fate of Wright's international reputation.

Clearly, Wright is a novelist with a few prominent sidelines: her short stories, her essays and criticism, and her one book of nonfiction, Grog War. Furthermore, she has edited an anthology titled Take Power Like This Old Man Here: An Anthology Celebrating Twenty Years of Land Rights in Central Australia, 1977-1997 (1998). And in between the publication of Carpentaria in 2006 and The Swan Book in 2013, Wright wrote the words to a musical performance titled Dirtsong (2009). This performance was a collaboration with the Black Arm Band Company that premiered at the Melbourne International Arts Festival in 2009. It featured original songs in a variety of Australian Aboriginal languages with a film as a backdrop to the live performance. In spite of these sidelines, Wright's primary identification is as a novelist.

The history of Australian Aboriginal novelists is relatively short. Monica Clare's Karobran (1978) is often identified as the first novel by an Australian Aboriginal author, while Archie Weller's The Day of the Dog (1981) is singled out as an early breakthrough. On the subject of Australian Aboriginal novelists, Heiss writes, "We have fewer writers in fiction than in other genres" (264). Kilner and Minter's statistics, which are current through 2014, identify eighty-six novels and novellas published by Australian Aboriginal authors-less than half the number of book-length works of life writing they are able to identify (8). Clearly, Wright's identification as a novelist places her outside the dominant tradition, but that does not mean scholars have neglected her writing. As of November 2019, AustLit records 130 works of "criticism" about Wright's writing, making her one of the most popular Australian Aboriginal authors for consideration by literary critics ("Alexis Wright").

One area where Wright is not well represented in criticism, however, is the topic of this very article-that is, critical consideration of her publishing history, which remains largely unexplored territory. One possible reason for this critical neglect is that, in the context of the publishing history of Australian Aboriginal literature, Wright appears to be an outlier; she does not reflect the tropes that define so much scholarly writing on the subject of Australian Aboriginal literature and its publishing history. Arguably the only trend Wright could be said to be emblematic of is her involvement with two Australian Aboriginal publishing houses (specifically Magabala Books and IAD Press), as well as her involvement with other publishing houses (most notably UQP) with a strong commitment to Australian Aboriginal writing. But even on this issue, Wright defies expectations by virtue 
of her relationship, since 2006, with Giramondo Publishing, to the exclusion of Australian Aboriginal publishing houses and other publishing houses with a strong commitment to Australian Aboriginal writing. As for the other trends that scholars have identified on the subject of Australian Aboriginal literature and its publishing history, Wright's contact with them appears almost incidental: she benefited from the growth of interest in Australian Aboriginal literature in the wake of the 1988 Australian bicentennial celebrations, but she was not published in the 1980s; she has published only one poem; and she has never published a book of life writing, though Grog War had the potential to be taken in this direction.

A fourth trend in scholarly writing on the subject of Australian Aboriginal literature and its publishing history, which does not apply to Wright but is important to mention, is that many scholars have observed the negative influence of non-Aboriginal editors who edit the works of Australian Aboriginal authors. Indeed, there exists an extraordinary amount of scholarly writing on this subject (see, e.g., Freeman; Hughes; Jones; McDonell). It would not be an exaggeration to say that the scholars responsible for producing this body of scholarly work are unanimous in their disapproval of this particular editor-author dynamic. However, Michael Jacklin is one scholar who is concerned by the obsessive focus on "editing and framing issues" that can be found in so many scholarly works about Australian Aboriginal writing: "The unease I had experienced when reading some critical analyses of indigenous texts had been prompted by ... non-indigenous critics devoting the majority of their attentions to editing and framing issues, to the neglect of the indigenous narrative, their putative object of study" (139). Stephen Muecke describes this focus as "direct[ing] all the critical attention to the linguistic strategies of the editors, as if these were the most salient features of the works" (45). Indeed, all of the trends discussed above, which scholars have identified on the subject of Australian Aboriginal literature and its publishing history, could be characterized as "editing and framing issues." Furthermore, this article about the publishing history of Wright is part of this same dynamic.

It is worth noting, however, that very little of what Wright has written has been subjected to this sort of analysis. An exception to this statement is Sandra R. Phillips's PhD dissertation, "Re/presenting Readings of the Indigenous Literary Terrain” (2011), in which Phillips writes in great detail about the acquisition, editing, and marketing of Carpentaria. Notably, she is not in the least bit critical of the role played by the non-Aboriginal editor at Giramondo Publishing in the production of Wright's novel. (It is perhaps no small coincidence that Phillips, a descendant of the Wakka Wakka and Goreng Goreng peoples of Southern Queensland, was formerly employed as an editor at UQP, where she edited Plains of Promise.) Phillips's stance on this issue is in stark contrast to the previously mentioned scholars who have written about the role of non-Aboriginal editors in the publication of Australian Aboriginal writing. 
Indeed, Phillips's stance is also in stark contrast to perhaps the only other scholar who has considered Wright's work with regard to "editing and framing issues." This scholar is Alison Ravenscroft, author of The Postcolonial Eye: White Australian Desire and the Visual Field of Race (2012), who gives little more than a footnote's worth of attention to the "editing and framing" of Wright's books. Nonetheless, on the subject of Carpentaria, Ravenscroft writes, "Whites' critical efforts to make meaning of Alexis Wright's Carpentaria have sought to anchor it to the big names among white Australian novelists. ... Critics and reviewers, too, tend to nod respectfully in the direction of the publisher, Ivor Indyk, attributing to him a creative influence that is rarely credited to a publisher of white-signed texts" (59n2). Ravenscroft then references several newspaper and magazine articles she believes to be guilty of this behavior. For example, the following excerpt taken from one of these articles would seem to be representative of the behavior Ravenscroft disapproves of:

Carpentaria, her second and most ambitious novel, was signed up by Ivor Indyk of Giramondo Press after being turned down by the bigger imprints in Australia. It has yet to be sold in Britain or America.

Mr Indyk gained considerable renown when an earlier novel he published, Shanghai Dancing by Brian Castro, won three literary prizes in Australia in 2004. If the same happens with Carpentaria it will say something about Ms Wright's writing talent and Mr Indyk's eye. (“Great Divide”)

A second article referenced by Ravenscroft further drives home her point about "attributing to [the editor] a creative influence that is rarely credited to a publisher of white-signed texts":

Eventually the manuscript reached Ivor Indyk, the Sydney academic and critic who edits Heat literary magazine and publishes books under his Giramondo imprint. He had taught Aboriginal writing at the University of Sydney in the ' 80 s and responded to the idea of different genres in the one book.

"I understood the way the language could be ungrammatical but expressive. I understood its power and really wanted to work on it." He reckons that Carpentaria will change Australian literature through its disregard of convention. (Steger)

Contrary to Ravenscroft's interpretation of these two passages, Phillips has a different explanation: "The fact of [Carpentaria's] wide-spread rejection was often noted by critics; Ivor Indyk though interprets such critical emphasis as a 'marketing ploy' that is 'always trotted out when a book does really well'" (168, quoting Indyk). In other words, Phillips would interpret these excerpts as part of a "marketing ploy" common to the book-publishing industry rather than "attributing to [the editor] a creative influence that is rarely credited to a publisher of white-signed texts." 
It is not difficult to find evidence to support Phillips's interpretation. For example, Bloomsbury Publishing, the British publishing house responsible for bringing the wildly popular Harry Potter series by J. K. Rowling to the world, touts on the website created for its headlining author, "Harry Potter and the Philosopher's Stone was sent to a number of publishers initially, all of whom rejected the manuscript. It took a year before her agent, Christopher Little, could make the call that J. K. Rowling had been waiting for" (Rowling). Clearly, in spite of the efforts of individuals such as Ravenscroft to bring Wright into line with the tropes that define so much scholarly writing on the subject of Australian Aboriginal literature and its publishing history, Wright's publishing history complicates these widely circulated narratives.

The metanarrative of these widely circulated narratives is, as has been previously discussed, the reductive trend of analyzing Australian Aboriginal literature on the basis of its "editing and framing issues." Of course, one way around this problem is to ignore completely the "editing and framing issues." This is already happening to a certain extent as the output of Australian Aboriginal writers has shifted away from life writing (and especially as-told-to life writing), and scholarship on the subject of Australian Aboriginal literature has followed suit. For reasons explicated earlier in this article, the perceived potential for negative influence by non-Aboriginal editors who edit the works of Australian Aboriginal authors is higher for life writing than for other genres. Therefore, in the face of changing ideoscapes-"from scenes of witness associated with testimonial life narrative late last century to engagements with fictional prose, both the novel and the short story, this century" (Osborne and Whitlock 3)-scholars are choosing to bypass "editing and framing issues" entirely.

However, that is not an option for scholars of Australian Aboriginal literature and its publishing history. Thus, by acknowledging that all published writing-not just Australian Aboriginal writing-is shaped by these same types of issues, it is possible to thread the needle in order to write a nonreductive article about Wright's publishing history. Situating Wright's writing in the larger contexts of Australian literature and the international literary marketplace-rather than siloing it within the limited context of Australian Aboriginal literature-suggests new trends that have gone unremarked by scholars of Australian Aboriginal literature and its publishing history. While this article has attempted to suggest some of the most promising among these new trends, many more await exploration. Because the field is quite new, this article is primarily descriptive and only just scratches the surface of what can be done using this approach.

If scholars are going to make any progress in their explorations of these new trends, it will be important for them to move beyond some of the trends that have claimed so much of their attention to date. As documented in this article, these trends overemphasize the 1980s, certain genres (especially poetry and life writing), Australian Aboriginal publishing houses, and non-Aboriginal editors. Focusing on these trends has resulted in a scholarly obsession with a type of Australian Aboriginal writing that is undoubtedly abundant but is not necessarily the most 
widely read. When thinking about which works of Australian Aboriginal writing are widely read, it is important to look beyond best-seller lists-where you will not find much Australian Aboriginal writing anyway. Many works with Australian Aboriginal creators are taught in schools and universities, however, which is likely to yield a large readership. Looking at the Teaching Australian Literature Resource website, only three of the top-twenty most frequently taught texts by Australian Aboriginal creators are works of life writing, while six of them are works of fiction (including five novels and one short story collection that can be read as a novel [AustLit, "Teaching"]). Furthermore, none of them are published by an Australian Aboriginal publishing house, and three-quarters were published since 1993. Even more impressive, Wright authored the most frequently taught text by an Australian Aboriginal creator, Carpentaria, as well as the eighth most frequently taught, Plains of Promise. Clearly, it is advisable that scholars of Australian Aboriginal literature and its publishing history modify their current methodologies to account for such a significant feature of their field.

Although Wright may not be emblematic of the trends that have been narrated in great detail by scholars of Australian Aboriginal literature and its publishing history, she is certainly emblematic of the need to expand beyond the frameworks currently governing this discussion. Doing so has the potential to challenge established ways of thinking about national and indigenous literary traditions, and the public's understanding of Australian Aboriginal literature will be richer for it.

\section{Notes}

1. A similar research methodology was employed to good effect in a chapter titled "Kim Scott's Publishing History in Three Contexts: Australian Aboriginal, National, and International" (Henningsgaard 9), which was included in A Companion to the Works of Kim Scott.

2. A much shorter version of this story was originally published in English in 1999 with the title "After the Storm." The changes that Wright made to "After the Storm" before it was translated into French and published as "Il y a de la lumière, mais personne à la maison" are described in Hall.

3. A translation into Catalan was planned by the Barcelona publishing house Club Editor, but the publisher "had to return the rights when they couldn't get support from the Australia Council" (Indyk). Nonetheless, many sources have mistakenly reported (see, for example, Stella Prize) that there is a translation of Carpentaria published in Spain.

4. The sales figures in this paragraph come courtesy of Nielsen BookScan, which provided complimentary academic access to its data. Nielsen provides statistics that are, according to an unpublished PowerPoint titled "BookScan: An Overview of the Nielsen BookScan System," and according to its own promotional materials, "Point-of-Sales data ... acquired from a growing list of retailers who send Nielsen scanned data on 500,000 ISBNs/14 million units from 16,000 locations a week. This data covers roughly $85 \%$ of the US trade physical book market."

\section{Works Cited}

AustLit. St Lucia: U of Queensland, 2002-. Web. http://www.austlit.edu.au.

—. "Alexis Wright: Works about their works." Web. 19 April 2020. http://www.austlit.edu/au/ austlit/page/A6167 
“Teaching Aust. Lit.” Web. 30 Mar. 2019. http://www.austlit.edu.au/austlit/page/7863737.

Barrett, Susan. "The Translation and Marketing of Australian Literature in France." Bernard Hickey, a Roving Cultural Ambassador: Essays in His Memory. Ed. Maria Renata Dolce and Antonella Riem Natale. Udine, Italy: Forum, 2009. 51-60. Print.

Barron, Michael. “Carpentaria.” Tin House 12 Feb. 2013. Web. http://www.tinhouse.com/blog/22745/ carpentaria.html.

Bennett, Bruce. "Literary Culture since Vietnam: A New Dynamic.” The Oxford Literary History of Australia. Ed. Bruce Bennett and Jennifer Strauss. Oxford: Oxford UP, 1998. 239-64. Print.

Campbell, Michael. "Writing the World: Successful International Exchange Collaborations.” Australian Arts: Where the Bloody Hell Are You? Ed. John Clark et al. Sydney: Sydney UP, 2007. 110-17. Print.

Čerče, Danica. "Reconstructing the Cultural Specificity of Indigenous Australian Writing in the Slovene Cultural Space.” Journal of Language, Literature and Culture 62.2 (2015): 77-88. Print.

Clare, Monica. Karobran. Sydney: Alternative Publishing Co-operative, 1978. Print.

Devitt, Marian. "Going with the Territory." Overland 152 (Spring 1998): 33. Print.

Ensor, Jason. "Reprints, International Markets and Local Literary Taste: New Empiricism and Australian Literature.” The Colonial Present. Spec. issue of JASAL (2008): 198-218. Web. “'Still Waters Run Deep': Empirical Methods and the Migration Patterns of Regional Publishers' Authors and Titles within Australian Literature.” Antipodes 23.2 (2009): 197-208. Print.

Everett, Kristina. "Too Much Information: When the Burden of Trust Paralyzes Representation." Indigenous Biography and Autobiography. Ed. Peter Read et al. Canberra: ANU E P, 2008. 147-57. Print.

Freeman, Robin. “'We Must Become Gatekeepers': Editing Indigenous Writing.” International Journal for the Practice and Theory of Creative Writing 6.2 (2009): 133-49. Print.

"A Great Divide-New Fiction from Australia." Economist 3 Mar. 2007: 382. Print.

Grundy, Alice. "Editor's Cut: Notes on the Chinese Publishing Industry." Sydney Review of Books 4 Nov. 2014. Web. https://sydneyreviewofbooks.com/chinese-publishing-industry/.

Haag, Oliver. "From the Margins to the Mainstream: Towards a History of Published Indigenous Australian Autobiographies and Biographies." Indigenous Biography and Autobiography. Ed. Peter Read et al. Canberra: ANU E P, 2008. 5-28. Print.

—. "Indigenous Australian Literature in German: Some Considerations on Reception, Publication and Translation." JASAL, "Special Issue: Australian Literature in a Global World" (2016): 1-17. Web.

Hall, Demelza. "Translating the Short Stories of Alexis Wright: Sylvie Kandé Talks to Demelza Hall about Le pacte du serpent arc-en-ciel (with Postscript by Alexis Wright).” JASAL 16.2 (2009): 1-9. Web.

Hanke, Andrea. “'Business as Usual' at Frankfurt Book Fair 2013.” Books+Publishing 14 Oct. 2013. Web. http://www.booksellerandpublisher.com.au/item/28553.

Heiss, Anita M. Dhuuluu-Yala-To Talk Straight: Publishing Indigenous Literature. Canberra: Aboriginal Studies P, 2003. Print.

Heiss, Anita, and Peter Minter. "Aboriginal Literature." Anthology of Australian Aboriginal Literature. Ed. Anita Heiss and Peter Minter. Montreal: McGill-Queen's UP, 2008. 1-8. Print.

Henningsgaard, Per. "Kim Scott's Publishing History in Three Contexts: Australian Aboriginal, National, and International." A Companion to the Works of Kim Scott. Ed. Belinda Wheeler. Rochester, NY: Camden House, 2016. 9-24. Print.

Hughes, Mary Ann. "An Issue of Authenticity: Editing Texts by Aboriginal Writers." Southerly 58.2 (1998): 48-58. Print.

Indyk, Ivor. "Question about Spanish-Language Rights for Carpentaria." Email to the publisher. 6 Feb. 2019. Email.

Jacklin, Michael. "Consultation and Critique: Implementing Cultural Protocols in the Reading of Collaborative Indigenous Life Writing." Indigenous Biography and Autobiography. Ed. Peter Read et al. Canberra: ANU E P, 2008. 135-45. Print. 
Jones, Jennifer. Black Writers, White Editors: Episodes of Collaboration and Compromise in Australian Publishing History. North Melbourne: Australian Scholarly Publishing, 2009. Print.

Kilner, Kerry, and Peter Minter. "The BlackWords Symposium: The Past, Present, and Future of Aboriginal and Torres Strait Islander Literature." JASAL 14.3 (2014): 1-10. Web.

Kurtzer, Sonja. "Wandering Girl: Who Defines 'Authenticity' in Aboriginal Literature?" Southerly 58.2 (1998): 20-29. Print.

Magabala Books. Home page. Web. 30 Mar. 2019. http://www.magabala.com.

McDonell, Margaret. "Protocols, Political Correctness and Discomfort Zones: Indigenous Life Writing and Non-Indigenous Editing." Hecate 30.1 (2004): 83-95. Print.

McKernan, Susan. "Crossing the Border: Regional Writing in Australia." Meanjin 45.4 (1986): 547-60. Print.

Mudrooroo. "Writing Aborigines into the Australian Story." Queensland Writers Centre Newsletter 42 (1996): 8. Print.

Muecke, Stephen. "The Scribes.” Meridian 3.1 (1984): 41-48. Print.

Munro, Craig. "Case-Study: Indigenous Writers." Paper Empires: A History of the Book in Australia, 1946-2005. Ed. Craig Munro and Robyn Sheahan-Bright. St Lucia: U of Queensland P, 2006. 150-56. Print.

Osborne, Roger, and Gillian Whitlock. "Carpentaria: Reading with the Dirt of Blurbs and Front Pages.” JASAL 16.2 (2016): 1-11. Web.

Phillips, Sandra R. "Re/presenting Readings of the Indigenous Literary Terrain." PhD diss., Queensland U of Technology, 2011. https://eprints.qut.edu.au/50838/1/Sandra_Phillips_ Thesis.pdf.

Poland, Louise. "An Enduring Record: Aboriginal Publishing in Australia 1988-1998." Australian Studies 16.2 (2001): 83-109. Print.

Ravenscroft, Alison. The Postcolonial Eye: White Australian Desire and the Visual Field of Race. Farnham, UK: Ashgate, 2012. Print.

Rowling, J. K. "Bloomsbury Publishing." Web. 30 Mar. 2019. http://www.jkrowling.com/en_GB/\#/ timeline/bloomsbury-publishing/.

Steger, Jason. "Humanity's Voice Rises." Age 23 June 2007: 2. Print.

Stella Prize. "Alexis Wright." Web. 30 Mar. 2019. https://thestellaprize.com.au/writer/alexis-wright/.

Stinson, Emmett. "In the Same Boat." Sydney Review of Books 26 Mar. 2013. Web. https:// sydneyreviewofbooks.com/in-the-same-boat/.

Syson, Ian. "Going with the Territory." Overland 152 (Spring 1998): 3. Print.

Thompson, John B. Merchants of Culture: The Publishing Business in the Twenty-First Century. Cambridge, UK: Polity, 2010. Print.

Turner, Graeme. Making It National: Nationalism and Australian Popular Culture. St Leonards: Allen and Unwin, 1994. Print.

Unaipon, David. Native Legends. Adelaide: Hunkin, Ellis and King, 1929. Print.

Walker, Kath. We Are Going. Brisbane: Jacaranda, 1964. Print.

Weller, Archie. The Day of the Dog. Sydney: Allen and Unwin, 1981. Print.

Wright, Alexis. "After the Storm." Sydney Morning Herald 7 Jan. 1999: 6. Print.

_. "Be Careful about Playing with the Path of Least Resistance." Freedom: Short Stories Celebrating the Universal Declaration of Human Rights. Ed. Amnesty International. Edinburgh: Mainstream, 2011. 217-28. Print.

-. Carpentaria. Artarmon: Giramondo, 2006. Print.

-. Carpentaria. London: Constable, 2008. Print.

—. Carpentaria. New York: Atria International, 2009. Print.

—. Carpentarie. Trans. Pierre Furlan. Paris: Actes Sud, 2009. Print.

—. "The Chinky Apple Tree." Across Country: Stories from Aboriginal Australia. Ed. Kerry Davies. Sydney: ABC Books, 1998. 218-23. Print. 
_. "The Chinky Apple Tree." Overland 152 (Spring 1998): 47-49. Print.

. "The Chinky Apple Tree." Siglo 10 (Autumn-Winter 1998): 40-43. Print.

—. Croire en l'incroyable. Trans. Sabine Porte. Paris: Actes Sud, 2000. Print.

—. "Dead Man's Mile." Voices from the Heart: Contemporary Aboriginal Poetry from Central Australia. Ed. Roger Bennett. Alice Springs: IAD, 1995. 64-65. Print.

—. Grog War. Broome: Magabala Books, 1997. Print.

—. Grog War. 2nd ed. Broome: Magabala Books, 2009. Print.

—. Le pacte du serpent arcen-ciel. Trans. Sylvie Kandé and Marc de Gouvenain. Paris: Actes Sud, 2002. Print.

—. Les plaines de l'espoir. Trans. Sabine Porte. Paris: Actes Sud, 1999. Print.

—. "On Writing Carpentaria." Heat 13 (2007): 79-95. Print.

Plains of Promise. St Lucia: U of Queensland P, 1997. Print.

"Politics of Writing." Southerly 62.2 (2002): 10-20. Print.

"A Question of Fear." Tolerance, Prejudice, and Fear: Sydney PEN Voices, the 3 Writers Project. Ed.

Sydney PEN Centre. Crows Nest, NSW: Allen and Unwin, 2008. 129-69. Print.

"Secrets and Ties." Age 6 Feb. 2010: 12-13. Print.

—. "The Serpent's Covenant." A Sea Change: Australian Writing and Photography. Ed. Adam Shoemaker. Sydney: Sydney Organising Committee for the Olympic Games, 1998. 180-91. Print.

_. "Special Feature: Hunger and Other Stories." English in Australia 137 (Winter 2003): 66-70. Print.

—. The Swan Book. Artarmon: Giramondo, 2013. Print.

—. The Swan Book. London: Constable, 2015. Print.

—. The Swan Book. New York: Atria International, 2016. Print.

—, ed. Take Power Like This Old Man Here: An Anthology Celebrating Twenty Years of Land Rights in Central Australia, 1977-1997. Alice Springs: IAD, 1998. Print.

—_. "Trapped in a Cycle of Fear." Sydney Morning Herald 30 June-1 July 2007: 28-29. Print.

—_. "Untitled (from Requiem for Ivy)." Meanjin 55.4 (1996): 597-610. Print.

—. "We Have a Vision. What We Need Is Authority." Advertiser 30 June 2007: 8-10. Print.

—. "When Devils Call." Extra-Territorial: Stories and Poems from the Northern Territory Literary Awards. Ed. Derek Wright. Darwin: NTU Press, 1996. 67-69. Print.

"When Devils Call." Across Country: Stories from Aboriginal Australia. Ed. Kerry Davies. Sydney: ABC Books, 1998. 224-28. Print.

"Where to Point the Spears?" Experiences of Freedom in Postcolonial Literatures and Cultures. Ed. Annalisa Oboe and Shaul Bassi. New York: Routledge, 2011. 35-42. Print.

Wright, Alexis, and the Black Arm Band Company. Dirtsong. World premiere performance. Melbourne International Arts Festival, 23-24 Oct. 2009.

Wyndham, Susan. “The Precarious Life of a Prize Winner." Sydney Morning Herald 30 June 2007. Web. http://blogs.smh.com.au/entertainment/archives/undercover/014326.html. 